\title{
Effect of Metakaolin Developed from Local Soorh on Fresh Properties and Compressive Strength of Self- Compacted Concrete
}

\author{
Abdullah Saand \\ Department of Civil Engineering \\ Quaid-e-Awam University of \\ Engineering, Science and Technology \\ Nawabshah, Pakistan \\ abdullah.saand@gmail.com
}

\author{
Karam Ali Jamali \\ Department of Civil Engineering \\ Quaid-e-Awam University of \\ Engineering, Science and Technology \\ Nawabshah, Pakistan \\ tespublic@yahoo.com
}

\author{
Manthar Ali Keerio \\ Department of Civil Engineering \\ Quaid-e-Awam University of \\ Engineering, Science and Technology \\ Nawabshah, Pakistan \\ mantharali99@quest.edu.pk
}

Tariq Ali

Department of Civil Engineering

Quaid-e-Awam University of Engineering, Science and

Technology, Nawabshah, Pakistan

tariqdehraj@gmail.com

\author{
Nadeem-ul-Karim Bhatti \\ Department of Civil Engineering \\ Quaid-e-Awam University of Engineering, Science and \\ Technology, Nawabshah, Pakistan \\ knadeem_b@quest.edu.pk
}

\begin{abstract}
This paper presents the fresh properties of SelfCompacting Concrete (SCC) containing metakaolin (MK) produced by calcination of the natural material soorh of district Thatta Sind in Pakistan. Five mixes were tested, including four MK mixes replacing $5-20 \%$ of cement, with 0.38 water/binder (W/B) ratio. The fresh properties of the SCCs were evaluated using slump flow, T50, V-funnel, $J$ ring, L-box and sieve segregation tests. Compressive strength of the control and the MK SCC was also investigated. The fresh concrete test results revealed that SCC could be developed by substituting cement with local MK, using $2 \%$ superplasticizers and without using a viscosity-modifying amplifier. The SCC with $15 \%$ replacement of cement with local MK showed maximum compressive strength, which was $10.39 \%$ higher than the control specimen's without MK.
\end{abstract}

Keywords-metakaolin; self-compacting concrete; soorh

\section{INTRODUCTION}

Self-compacting concrete (SCC) is a highly flowable concrete, which can be installed and compacted without any vibration in complex or dense reinforced formworks. In order to achieve such behavior, the main requirements of fresh SCC are filling ability, passing ability and very high segregation resistance. The first two properties can be achieved by using a high-range water reducer (HRWR) admixture. To secure the stability/cohesion of the mix, a large quantity of powder materials and/or viscosity-modifying admixture (VMA) is required. According to [1], the term powder is defined for materials of particle size smaller than $0.125 \mathrm{~mm}$, which include a fraction of aggregate additions and cement. Portland cement is a high energy-intensive product. On the other hand, about $7 \%$ of total $\mathrm{CO}_{2}$ emissions are produced by the cement industry [2]. In addition, some disadvantages in the properties of concrete have been reported as the cement content exceeded a specified value [3]. To minimize these negative effects, the requirement to increase powder content in SCC is usually met by using additions. For this purpose, various studies have been conducted on the usage of different additions for partially replacing cement in SCC or self-compacted mortar such as marble powder $[4,5]$, limestone powder [6], basalt powder [5, 6], fly ash [7-9], slag [10, 11], MK [12-16], and other materials[17-22]. Today global warming and energy crisis are major issues. The manufacture of one ton of cement emits approximately 0.8 tons of $\mathrm{CO}_{2}$ into the atmosphere, which accounts about the $5-8 \%$ of worldwide $\mathrm{CO}_{2}$ emissions $[23,24]$. Moreover, cement production emissions include also $\mathrm{SO}_{3}$ and $\mathrm{NO}_{\mathrm{x}}[24,25]$. Cement production requires huge energy, as it needs temperatures of $1600-1900^{\circ} \mathrm{C}$, adding up to the energy crisis in many countries, such as Pakistan, where the cost of cement is rising resulting in an overall rise in the construction cost. This study proposes a method that increases the properties of SCC and reduces the cement production, reducing consequently both $\mathrm{CO}_{2}$ emissions and construction cost, by replacing cement with local MK.

\section{MATERIALS USED}

\section{A. Cement}

Ordinary Portland cement (OPC) from a brand named Lucky, has been used in this research. Its chemical composition and physical properties are shown in Table I.

\section{B. Fine Aggregates}

The aggregates used are composed of hill sand passing from $4.75 \mathrm{~mm}$, crushed stone passing from $12 \mathrm{~mm}$ and retained on $4.75 \mathrm{~mm}$ sieves. 


\section{Local Metakaolin}

Local metakaolin (MK) was produced from local natural material soorh available at district Thatta Sindh in Pakistan, by calcination at $800^{\circ} \mathrm{C}$ for 2 hours. The MK was used as cement replacement at various dosages, after sieving it from a sieve No 325. The chemical composition and physical properties comparison of OPC, soorh and developed $\mathrm{MK}$ are presented in Table I.

TABLE I. CHEMICAL COMPOSITION OF MATERIALS [26]

\begin{tabular}{|l|c|c|c|}
\hline \multicolumn{1}{|c|}{ Constituents } & $\begin{array}{c}\text { Percentage by } \\
\text { cement weight }\end{array}$ & $\begin{array}{c}\text { Percentage by } \\
\text { soorh weight }\end{array}$ & $\begin{array}{c}\text { Percentage by } \\
\text { MK weight }\end{array}$ \\
\hline $\mathbf{S i O}_{2}$ & 20.78 & 55.89 & $62.18 \%$ \\
\hline $\mathbf{A l}_{\mathbf{2}} \mathbf{O}_{3}$ & 5.11 & 23.51 & $21.67 \%$ \\
\hline $\mathbf{C a O}$ & 60.89 & - & $3.01 \%$ \\
\hline $\mathbf{M g O}$ & 3 & 3.53 & $3.41 \%$ \\
\hline $\mathbf{F e}_{\mathbf{2}} \mathbf{O}_{3}$ & 3.17 & 8.15 & $6.05 \%$ \\
\hline $\mathbf{K}_{\mathbf{2}} \mathbf{O}$ & - & 5.89 & $1.85 \%$ \\
\hline $\mathbf{N a}_{2} \mathbf{O}_{3}$ & - & 1.89 & $1.03 \%$ \\
\hline $\mathbf{T i O}_{2}$ & - & 1.14 & $1.03 \%$ \\
\hline $\mathbf{I n}_{\mathbf{2}} \mathbf{O}_{3}$ & - & - & $0.8 \%$ \\
\hline $\mathbf{L O I}(\%)$ & 1.71 & 7.4 & 0.5 \\
\hline $\begin{array}{l}\mathbf{B l a i n e}_{3} \text { specific } \\
\text { surface area }\left(\mathbf{c m}^{2} / \mathbf{g}\right)\end{array}$ & 3008 & 2101 & 2339 \\
\hline
\end{tabular}

III. MIXTURE PROPORTION

Based on the $\mathrm{W} / \mathrm{B}$ ratio of 0.38 , SCC mixtures were prepared following [1]. The reference concrete was prepared by only OPC while in the other mixtures OPC was partially replaced by MK at 5\%,10\%, 15\% and $20 \%$ of the cement's weight. Details of mix proportions are exhibited in Table II.

TABLE II. MIX PROPORTIONS

\begin{tabular}{|c|c|c|c|c|c|c|c|}
\hline $\begin{array}{c}\text { Concrete } \\
\mathbf{m i x}\end{array}$ & $\begin{array}{c}\text { Cement } \\
\left(\mathbf{k g} / \mathbf{m}^{\mathbf{3}}\right)\end{array}$ & $\begin{array}{c}\text { MK } \\
\left(\mathbf{k g} / \mathbf{m}^{\mathbf{3}}\right)\end{array}$ & $\begin{array}{c}\text { Total binder } \\
\left(\mathbf{k g} / \mathbf{m}^{\mathbf{3}}\right)\end{array}$ & $\begin{array}{c}\text { Water } \\
\left(\mathbf{k g} / \mathbf{m}^{\mathbf{3}}\right)\end{array}$ & $\begin{array}{c}\mathbf{F A} \\
\left(\mathbf{k g} / \mathbf{m}^{\mathbf{3}}\right)\end{array}$ & $\begin{array}{c}\mathbf{C A} \\
\left(\mathbf{k g} / \mathbf{m}^{\mathbf{3}}\right)\end{array}$ & $\begin{array}{c}\mathbf{S P} \\
(\mathbf{\%})\end{array}$ \\
\hline CM & 500 & - & 500 & 190 & 900 & 650 & 2 \\
\hline MK5 & 475 & 25 & 500 & 190 & 900 & 650 & 2 \\
\hline MK10 & 450 & 50 & 500 & 190 & 900 & 650 & 1 \\
\hline MK15 & 425 & 75 & 500 & 190 & 900 & 650 & 3 \\
\hline MK20 & 400 & 100 & 500 & 190 & 900 & 650 & 3 \\
\hline
\end{tabular}

$\mathrm{M} / \mathrm{B}=0.38$

\section{TEST PROCEDURE}

The fresh properties of SCC have been studied out by using the method specified in [1]. The filling ability tests respected slump flow using $\mathrm{V}$-funnel and $\mathrm{T}_{50}$ flow time test, while passing ability tests, such as J-Ring and L-box, were also carried out. Moreover, sieve segregation test was carried out. Various trial mixes with and without superplasticizers were prepared to develop the SCC. Twenty eight days after the development of the control and the modified MK SCC, the compressive strength of concrete was evaluated using BS EN 12390-3.

\section{RESULTS AND DISCUSSION}

\section{A. Slump Flow}

Slump flow test was used to assess the horizontal free flow of SCC in the absence of obstructions. The diameter of the concrete circle is a measure of the filling ability of concrete [1].
The results of slump flow test for the mixtures are shown in Figure 1.

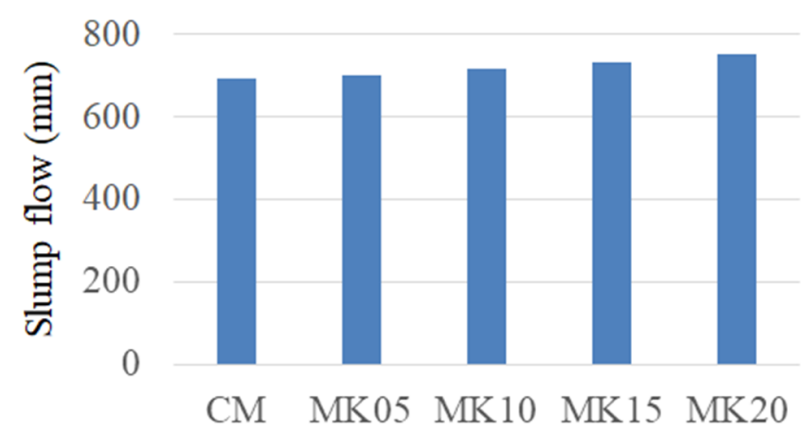

Fig. 1. Slump flow of control and metakaolin SCC

The recommended values of slump flow in [1] are 650$850 \mathrm{~mm}$. Without using superplasticizers and using only $1 \%$ superplastericizers, the observed slump flow of control and MK SCC was less than the recommended. By using $2 \%$ superplasticizers the slump flow of control and MK SCC was within the recommended range. As the quantity of MK increased the slump flow increased due to MK's less specific surface area as compared to cement.

\section{B. V-Funnel}

This test was developed in Japan and used in [27]. The Vfunnel test is used to determine the filling ability (flowability) of the concrete with a maximum aggregate size of $20 \mathrm{~mm}$. The results of the V-Funnel test are shown in Figure 2.

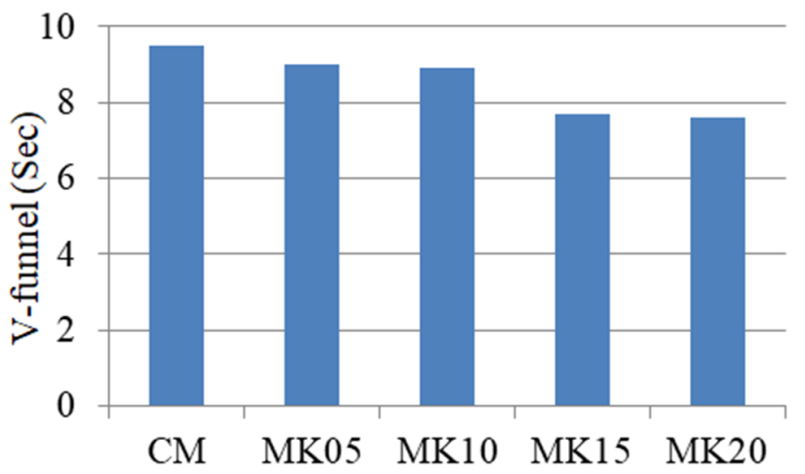

Fig. 2. V-funnel of control and metakaolin self compacted concrete

The recommended values [1] of the V-funnel are 6-12sec [1]. Without using superplasticizers and using $1 \%$ superplasticizers, the observed V-funnel flow of the control and the MK SCCs exceeded the recommended range. By using $2 \%$ superplasticizers the V-funnel of the control and the MK SCC were within the recommended range. As the quantity of $\mathrm{MK}$ increased, the V-funnel time decreased.

\section{T50 Flow}

T50 flow test was used to assess the horizontal free flow of SCC in the absence of obstructions. The results of the T50 flow tests are shown in Figure 3. 


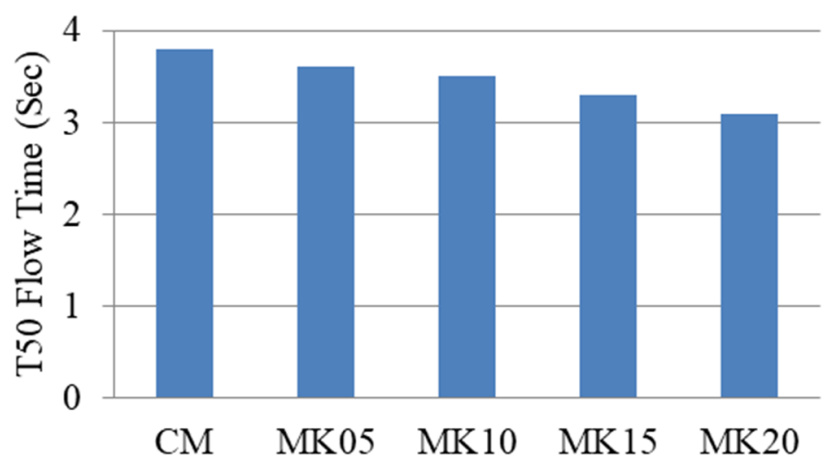

Fig. 3. T50 flow of control and metakaolin SCC

The recommended values of T50 flow time are $2-5 \mathrm{sec}$ [1]. Without using superplasticizers and using $1 \%$ superplastericizers, the observed T50 flow time of the control and the MK SCC exceeded the recommended. By using 2\% superplasticizers, the T50 values of the control and the MK SCC were observed within the recommended range. As the quantity of MK increased the T50 flow decreased.

\section{J-Ring}

The J-Ring test was developed at the University of Paisley and it is used to determine the passing ability of the concrete. The results J-Ring tests are shown in Figure 4.

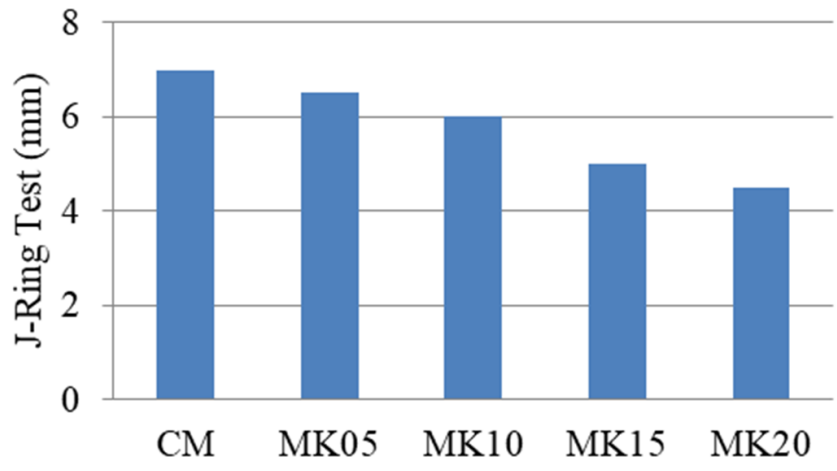

Fig. 4. J-Ring of control and metakaolin self compacted concrete

The recommended values of J Ring test [1] are $0-10 \mathrm{~mm}$. Without using superplasticizers and using $1 \%$ superplastericizers, the observed values of the control and the MK SCC exceeded the recommended. By using $2 \%$ superplasticizers the observed J-Ring values of the control and the MK SCC were within the recommended range. As the quantity of MK increased, J-Ring decreased.

\section{E. L-Box}

L-Box test is used to assess the flow of the concrete and the extent to which it is subject to blocking by reinforcement. The results of L-Box tests are shown in Figure 5. The recommended values for the L-Box test are 0.8-1.0. Without using superplasticizers and using $1 \%$ superplasticizer, the observed values of control and the MK SCC exceed the recommended range. By using $2 \%$ superplasticizers the L-box value of control and the MK SCC were observed within the recommended range. Again, as the quantity of MK increased the L-box is decreased.

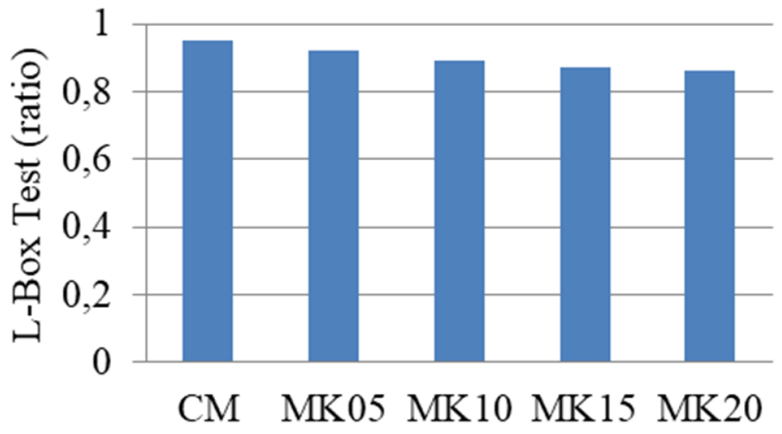

Fig. 5. L-Box ratio of control and metakaolin self compacted concrete

\section{F. Sieve Segregation Test}

The sieve segregation test was developed by GTM to assess segregation resistance (stability). The results of the sieve segregation tests are shown in Figure 6.

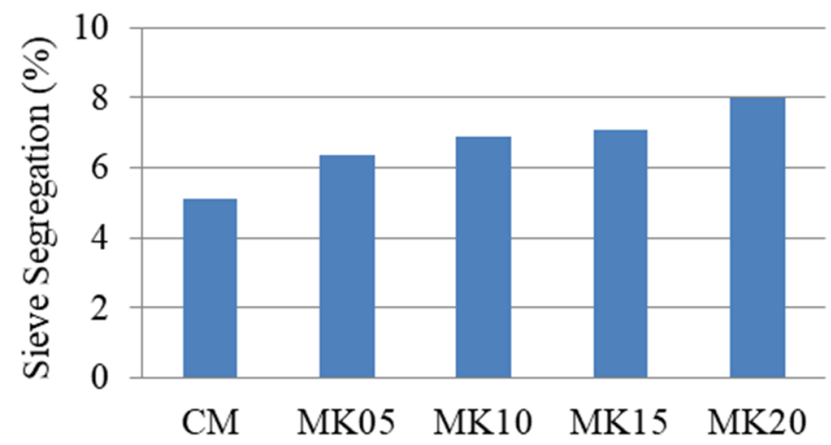

Fig. 6. Sieve segregation of control and metakaolin self compacted concrete

The recommended range of sieve segregation is $0-12 \%$ [1]. Without using superplasticizers and using $1 \%$ superplasticizers, the observed values of the control and the MK SCC exceeded the recommended range. By using $2 \%$ superplasticizers, the JRing values of control and MK SCC were within the recommended range. As the quantity of $\mathrm{MK}$ increased the sieve segregation increased.

\section{G. Compressive Strength}

The results of compressive strength tests are shown in Figure 7. The test results show that the compressive strength of $5-15 \%$ MK SCC increased compared to the control or the other MK SCCs. The 15\% MK mixture exhibited maximum compressive strength, being $10.39 \%$ higher than the one of the control mix.

\section{CONCLUSION}

This study evaluated the fresh properties of SCC containing local MK. Results showed that all the fresh properties of SCC containing local MK with $2 \%$ superplasticizers like passing ability, filling ability, and sieve segregation tests are within the recommended range. The fresh concrete test results revealed 
that SCC could be developed substituting cement with local MK up to $20 \%$, by using $2 \%$ superplasticizers, without using any viscosity-modifying admixture. Compressive strength of 5$15 \% \mathrm{MK}$ mixtures was increased, while in higher MK mixtures the compressive strength decreased. The $15 \% \mathrm{MK} \mathrm{SCC}$ had the maximum compressive strength, which was $10.39 \%$ higher than the control mix without MK.

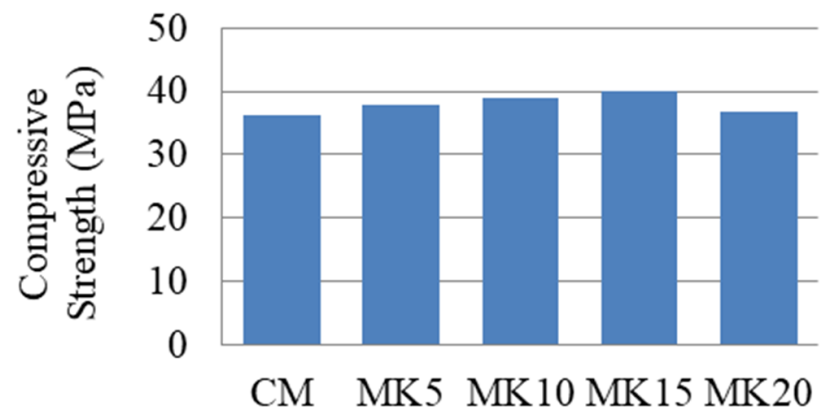

Fig. 7. Compressive strength of control and metakaolin Self compacted concrete

\section{ACKNOWLEDGEMENT}

Authors acknowledge the Quaid-e-Awam University for the provision of the necessary funds.

\section{REFERENCES}

[1] EFNARC, The European guidelines for self-compacting concrete; specification production and use, available at: http://www.efnarc.org/pdf/SCCGuidelinesMay2005.pdf, 2005

[2] R. Zerbino, G. Giaccio, G. C. Isaia, "Concrete incorporating rice-husk ash without processing", Construction and Building Materials, Vol. 25, No. 1, pp. 371-378, 2011

[3] A. M. Neville, Properties of concrete, Vol. 4, Longman, 1995

[4] E. Guneyisi, M. Gesoglu, E. Ozbay, "Effects of marble powder and slag on the properties of self compacting mortars", Materials and Structures, Vol 42, No. 6, pp. 813-826,2009

[5] M. Uysal, M. Sumer, "Performance of self-compacting concrete containing different mineral admixtures", Construction and Building Materials, Vol. 25, No. 11, pp. 4112-4120, 2011

[6] M. Uysal, K. Yilmaz, "Effect of mineral admixtures on properties of self-compacting concrete", Cement and Concrete Composites, Vol. 33, No. 7, pp. 771-776, 2011

[7] J. M. Khatib, "Performance of self-compacting concrete containing fly ash", Construction and Building Materials, Vol. 22, No. 9, pp. 19631971, 2008

[8] E. Guneyisi, M. Gesoglu, E. Ozbay, "Evaluating and forecasting the initial and final setting times of self-compacting concretes containing mineral admixtures by neural network", Materials and Structures, Vol. 42, No. 4, pp. 469-484, 2009

[9] M. Sahmaran, I. O. Yaman, M. Tokyay, "Transport and mechanical properties of self consolidating concrete with high volume fly ash", Cement and Concrete Composites, Vol. 31, No. 2, pp. 99-106, 2009

[10] O. Boukendakdji, S. Kenai, E. H. Kadri, F. Rouis, "Effect of slag on the rheology of fresh self-compacted concrete", Constuction and Building Materials, Vol. 23, No. 7, pp. 2593-2598, 2009

[11] J. M. Khatib, J. J. Hibbert, "Selected engineering properties of concrete incorporating slag and metakaolin", Construction and Building Materials, Vol. 19, No. 6, pp. 460-472, 2005

[12] G. Azeredo, M. Diniz, "Self-compacting concrete obtained by the use of kaolin wastes", Construction and Building Materials, Vol. 38, pp. 515523,2013
[13] I. P. Sfikas, E. G. Badogiannis, K. G. Trezos, "Rheology and mechanical characteristics of self-compacting concrete mixtures containing metakaolin", Construction and Building Materials, Vol.64, pp. 121-129, 2014

[14] R. Madandoust, S. Y. Mousavi, "Fresh and hardened Properties of selfcompacting concrete containing metakaolin", Construction and Building Materials, Vol. 35, pp. 752-760, 2012

[15] O. R. Kavitha, V. M. Shanthi, G. P Arulraj, V. R. Sivakumar, "Microstructural studies on eco-friendly and durable self-compacting concrete blended with metakaolin", Applied Clay Science, Vol. 124, pp. 143-149, 2016

[16] O. Karahan, K. M. A. Hossain, E. Ozbay, M. Lachemi, E. Sancak, "Effect of metakaolin content on the properties self-consolidating lightweight concrete", Construction and Building Materials, Vol. 31, pp. 320-325, 2012

[17] R. Sharma, R. A. Khan, "Influence of copper slag and metakaolin on the durability of self compacting concrete", Journal of Cleaner Production, Vol. 171, pp. 1171-1186, 2018

[18] Q. Ren, Z. Jiang, H. Li, X. Zhu, Q. Chen, "Fresh and hardened properties of self-compacting concrete using silicon carbide waste as a viscosity-modifying agent", Construction and Building Materials, Vol. 200, pp. 324-332, 2019

[19] M. Hajforoush, R. Madandoust, M. Kazemi, "Effects of simultaneous utilization of natural zeolite and magnetic water on engineering properties of self-compacting concrete", Asian Journal of Civil Engineering Vol. 20, No. 2, pp. 289-300, 2019

[20] Y. F. Silva, D. A. Lange, S. Delvasto, "Effect of incorporation of masonry residue on the properties of self-compacting concretes", Construction and Building materials, Vol. 196, pp.277-283, 2019

[21] A. Saand, M. A. Keerio, D. K. Bangwar, "Effect of soorh metakaolin on concrete compressive strength and durability", Engineering Technology \& Applied Science Research, Vol. 7, No. 6, pp. 2210-2214, 2017

[22] N. A. Memon, M. A. Memon, N. A. Lakho, F. A. Memon, M. A. Keerio, A. N. Memon, "A review on self compacting concrete with cementitious materials and fibers", Engineering, Technology \& Applied Science Research Vol. 8, No. 3, pp. 2969-2974, 2018

[23] A. M. Rashad, S. R. Zeedan, "The effect of activator concentration on the residual strength of alkali-activated fly ash pastes subjected to thermal load", Construction and Building Materials, Vol. 25, No. 7, pp. 3098-3107, 2011

[24] K. L. Scrivener, R. J. Kirkpatrick, "Innovation in use and research on cementitious material", Cement and Concrete Research, Vol. 38, No. 2, pp. 128-136, 2008

[25] S. S. Park, H. Y. Kang, "Characterization of fly ash-pastes synthesised at different activator conditions", Korean Journal of Chemical Engineering, Vol. 25, No. 1, pp.78-83, 2008

[26] A. Saand, M. A. Keerio, D. K. Bangwar, M. K. Samo, "Development of metakaolin as a pozzolanic material from local natural material, soorh", Arabian Journal for Science and Engineering, Vol. 41, No. 12, pp. 49374944, 2016

[27] K. Ozawa, N. Sakata, H. Okamura, "Evaluation of self-compactability of fresh concrete using the funnel test", Proceeding of Japan Society of Civil Engineering, Vol. 23, No. 490, pp. 71-80, 1994 (in Japanese) 